\title{
Diamenty w kolorach fantazyjnych - charakterystyka walorów inwestycyjnych
}

Marcin Potrykus*

\section{Wprowadzenie}

W czasach kryzysów na rynkach inwestycji tradycyjnych inwestorzy poszukują alternatywnych form pomnażania kapitału. Jedną z wielu takich inwestycji, określanych mianem alternatywnych, jest inwestycja w diamenty. Diamenty zajmują niepodważalne miejsce wśród inwestycji w kamienie szlachetne. Najbardziej rozpowszechnione są jednak inwestycje w kamienie bezbarwne. Tymczasem na rynku występują także naturalne diamenty w kolorach fantazyjnych (ang. fancy colored diamonds), takich jak: niebieski, różowy, czerwony, pomarańczowy czy zielony. Cechą charakterystyczną diamentów w kolorach fantazyjnych jest ich rzadkość występowania. Podkreśla się, że tylko jeden na tysiąc wydobytych diamentów to kamień w kolorze fantazyjnym (Fink 2014), chociaż inne źródła wskazują, że jest to jeden na 10 tysięcy kamieni ${ }^{1}$. Stąd na aukcjach renomowanych domów aukcyjnych ${ }^{2}$ ceny sprzedaży kolorowych diamentów osiągają bardzo wysokie ceny, przekraczające miliony dolarów (Shor 2013).

Celem poniższego opracowania jest wskazanie kryteriów, które decydują o przypisaniu do konkretnego diamentu określonej barwy. Ponadto w pracy zbadano, jak barwa, ton oraz nasycenie wpływają na wycenę diamentów w kolorach fantazyjnych. Za pomocą regresji hedonicznej zbadano, jak zmieniła się wartość analizowanych kamieni w 2015 roku. Do realizacji powyższych celów zastosowano metodę regresji hedonicznej ze względu na możliwość oceny w tej metodzie wpływu poszczególnych czynników na wycenę kamienia.

\footnotetext{
* Marcin Potrykus, Politechnika Gdańska, Wydział Zarządzania i Ekonomii, Katedra Analizy Ekonomicznej i Finansów.

1 http://www.gia.edu/fancy-color-diamond (dostęp: 17.12.2015).

2 Do najbardziej uznanych domów aukcyjnych na świecie zaliczają się dom aukcyjny Christie's oraz dom aukcyjny Sotheby's.
} 


\section{Metodologia określania koloru diamentu}

W przypadku inwestowania $\mathrm{w}$ diamenty niepodważalną rolę $\mathrm{w}$ powodzeniu inwestycji odgrywają cechy oznaczone jako „4C". Pod tym skrótem zawarto następujące charakterystyki diamentów:

- masa kamienia (ang. caratage),

- czystość (ang. clarity),

- jakość szlifu (ang. cut),

- kolor (ang. colour).

Dla trzech ostatnich cech, wymienionych powyżej, powstały specjalne skale służące do ich pomiaru ${ }^{3}$. Dla koloru jest to podziałka, w której zastosowano oznaczenia literowe (od litery „D”, oznaczającej bezbarwny kamień, do litery „Z”, którą oznacza się kamienie o bardzo jasnej, najczęściej żółtej barwie). Skala ta została zaproponowana przez instytucję GIA 4 . Za jej pomocą nie można jednak oceniać diamentów w kolorach fantazyjnych. Dlatego na potrzeby standaryzacji diamentów w kolorach fantazyjnych, instytucja GIA zaproponowała przyjęty (z różnymi modyfikacjami) niemal na całym świecie system oceny kolorowych diamentów, który kładzie nacisk na barwę (ang. hue), ton (ang. tone) i nasycenie (ang. saturation). Pod powyższymi określeniami należy rozumieć (King, Moses, Shigley, Liu 1994):

- Barwa - pozwala sklasyfikować dany kamień jako na przykład czerwony, żółty, zielony czy niebieski lub jakikolwiek pośredni spomiędzy nich.

- Ton - pozwala określić, czy dana barwa jest jasna czy ciemna.

- Nasycenie - inaczej natężenie zabarwienia, określa siłę i czystość barwy.

Dla barwy wyróżniono 27 różnych stopni, które przedstawiono na rysunku 1.

Tak jak to zaprezentowano, poza precyzyjnie zdefiniowanymi kolorami, takimi jak: żółty (ang. yellow), zielony (ang. green), niebieski (ang. blue), fioletowy (ang. purple) oraz czerwony (ang. red) i pomarańczowy (ang. orange), występują także kamienie, których nazwy kolorów składają się z dwóch wcześniej wymienionych barw. Przy tak złożonej nazwie należy pamiętać, że kolor, który wymieniony jest jako ostatni, to dominujący kolor ocenianego kamienia. Dodatkowo, jeżeli pierwszy kolor to zdrobnienie koloru podstawowego, np. zielonkawy (ang. greenish), żółtawy (ang. yellowish) itd., to udział tego pierwszego koloru w ostatecznej barwie kamienia jest nieznaczny. Dla nazw złożonych mogą zatem występować następujące przypadki: ${ }^{5}$

- niebieskawo-zielony (ang. bluish green) - dominujący udział w kolorze tego kamienia stanowi barwa zielona, a kolor niebieski jest jedynie domieszką barwy dominującej. Zakłada się, że udział barwy podstawowej to minimalnie około $75 \%$ ostatecznego koloru, a domieszki maksymalnie około $25 \%$.

3 Szerzej na temat klasyfikacji 4C w publikacjach (Jagielnicki 2011; Ostrowska 2011).

4 GIA - Gemological Institute of America.

5 Dokładne omówienie barw dla diamentów w kolorach fantazyjnych można odnaleźć w pracach (Hofer 1998; Matlins, Bonanno 1989). 
- niebiesko-zielony (ang. blue green) - obie barwy występują niemal w identycznych proporcjach z przewagą barwy zielonej.

- zielono-niebieski (ang. green blue) - obie barwy występują niemal w identycznych proporcjach z przewagą barwy niebieskiej.

- zielonkawo-niebieski (ang. greenish blue) - dominujący udział w kolorze tego kamienia stanowi barwa niebieska, a barwa zielona jest jedynie domieszką dla barwy dominującej.

Ponadto należy także pamiętać, że występują diamenty w kolorach, takich jak brązowy, szary i różowy. Powstają one z wyżej wymienionych kolorów, ale w sytuacji, gdy ton barwy jest jasny (kolor różowy lub brązowy) lub gdy ton barwy jest ciemny (kolor brązowy lub szary) ${ }^{6}$. Co więcej istotnym aspektem pozostaje także ocena, czy dany diament posiada naturalną barwę, czy też jest to kamień syntetyczny (Breeding, Shigley 2009).

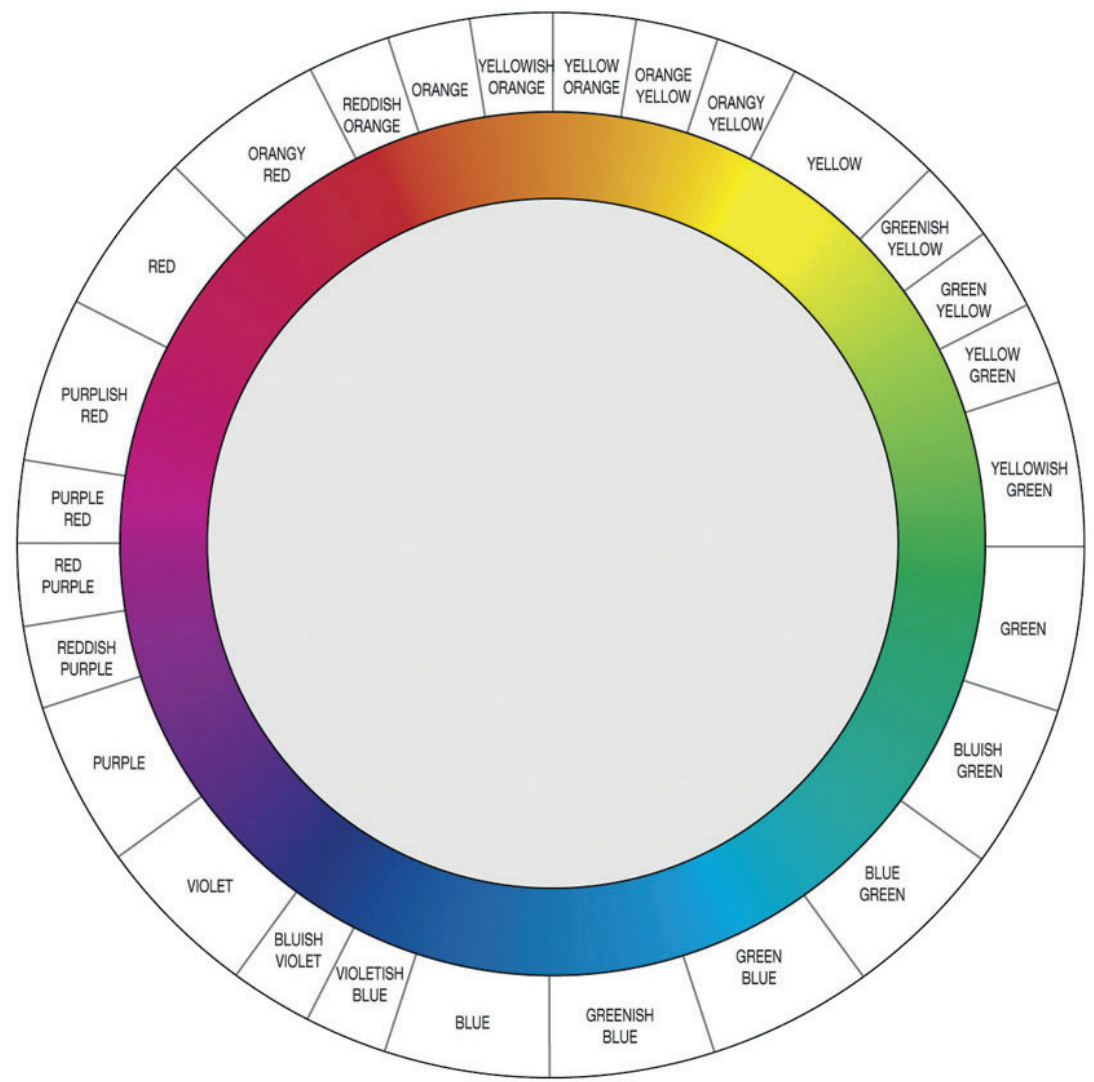

Rysunek 1. Barwy diamentów w kolorach fantazyjnych - skala GIA Źródło: http://4csblog.gia.edu/2014/celebrate-20-years-coloreddiamond-grading-system (dostęp: 17.12.2015).

6 Szerzej o wszystkich kolorach dla jasnego oraz ciemnego tonu w pracy (King 2006). 
Dla oznaczenia tonu i nasycenia koloru zostały wprowadzone terminy przedstawione na rysunku 2. Wszystkie terminy z rysunku dotyczą koloru żółtego, ale analogiczne terminy są stosowane dla pozostałych barw. Co więcej ton oraz nasycenie badane są łącznie i pod poszczególnymi nazwami kryją się określone kombinacje tych dwóch czynników.

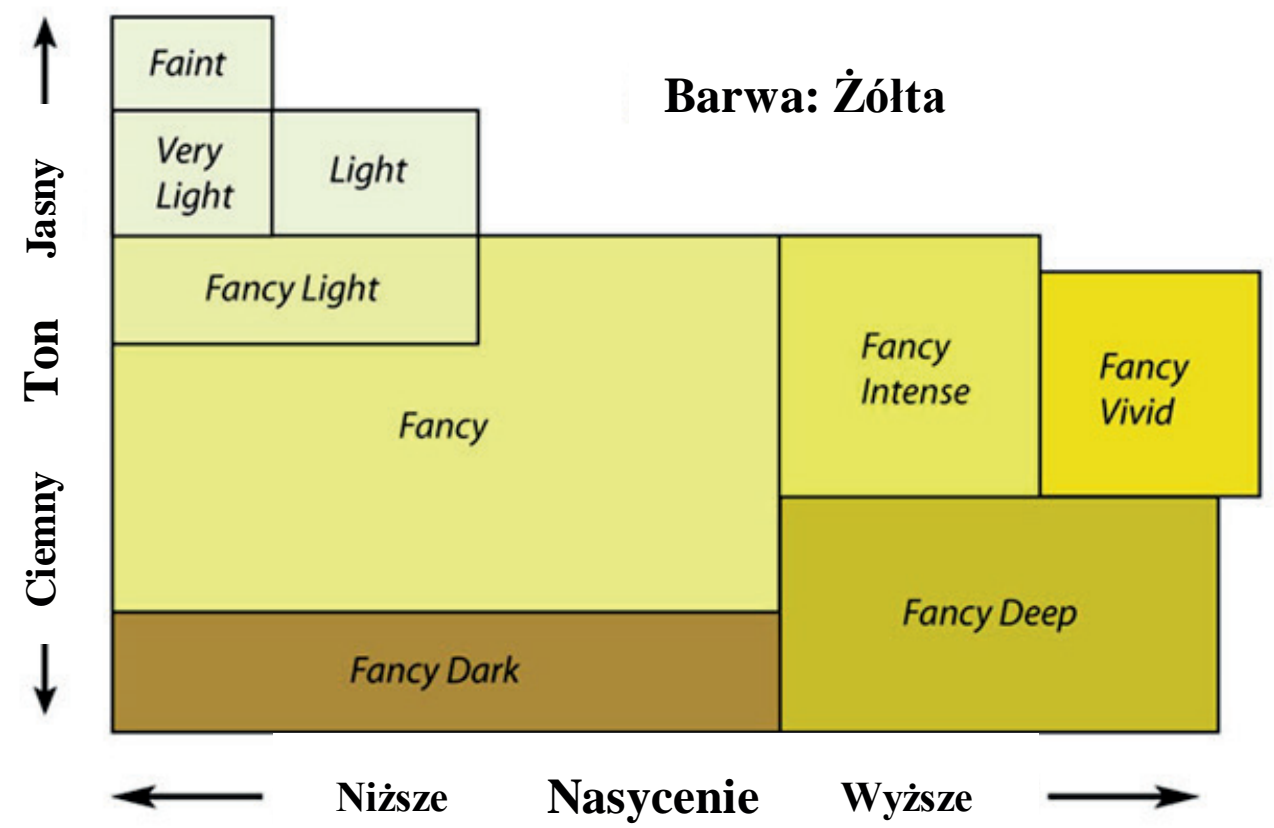

Rysunek 2. Ton oraz nasycenie - możliwe warianty dla diamentów w kolorach fantazyjnych Źródło: http://4csblog.gia.edu/2014/celebrate-20-years-colored-diamond-grading-system (dostęp: 17.12.2015).

Jak zaprezentowano na rysunku 2, dla określenia odpowiednich kombinacji tonu oraz nasycenia barwy można się posłużyć jednym z dziewięciu terminów:

- blady lub niewyraźny (ang. faint),

- bardzo jasny (ang. very light),

- jasny (ang. light),

- jasno-fantazyjny (ang. fancy light),

- fantazyjny (ang. fancy),

- ciemno-fantazyjny (ang. fancy dark),

- intensywnie-fantazyjny (ang. fancy intense),

- głęboko-fantazyjny (ang. fancy deep),

- żywo- lub ostro-fantazyjny (ang. fancy vivid).

Za pomocą powyższych nazw możliwe jest określenie kamieni jako bladych, gdy cechują się one bardzo jasnym tonem oraz bardzo niskim poziomem nasycenia. Odpowiednio, kamienie określane jako żywo- lub ostro-fantazyjne cechują się umiarkowanym tonem oraz bardzo wysokim poziomem nasycenia. 


\section{Badania literaturowe oraz charakterystyka danych}

Dotychczasowe badania literaturowe potwierdziły rosnące zainteresowanie inwestorów kamieniami szlachetnymi, w tym diamentami w kolorach fantazyjnych. Niepodważalną rolę na tym rynku odgrywają domy aukcyjne, które przyczyniły się do wzrostu obrotów na rynku kamieni szlachetnych. W ostatnich 30 latach wartość rynku aukcyjnego związana ze sprzedażą kamieni szlachetnych wzrosła z 50 milionów dolarów do blisko jednego miliarda (Shor 2013). Do rozwoju rynku kamieni w kolorach fantazyjnych przyczynia się również rozwój systemu oceny takich diamentów (King 1994). Powoduje to porównywalność poszczególnych kamieni i pozwala inwestorowi na wybór najlepszych diamentów do portfela inwestycyjnego. Co więcej na analizowanym rynku dąży się do eliminowania diamentów z państw, które z ich wydobycia finansują działania wojenne lub działania terrorystyczne (Betts, Nikischer 2014), co również ma zapewnić transparentność na rynku.

Pomimo licznych działań, mających na celu standaryzację oceny diamentów, można zaobserwować, że pomiędzy poszczególnymi instytucjami, certyfikującymi kamienie szlachetne, występują statystycznie istotne różnice. Okazuje się, że kamienie certyfikowane przez instytucję EGL USA były sprzedawane po niższych cenach niż diamenty, które posiadały certyfikat instytucji GIA. Średnia różnica w wycenie kamieni pomiędzy tymi instytucjami wyniosła blisko 16\%. Z kolei kamienie certyfikowane przez firmę AGS były przeciętnie droższe o ponad 23\% niż te, które posiadały certyfikat wydany przez GIA. Jako wyjaśnienie tych różnić wskazano relatywnie krótki czas certyfikowania kamieni przez instytucję EGL USA ${ }^{7}$ oraz aferę łapówkową z udziałem firmy GIA ${ }^{8}$ (Lee, Caudill, Mixon 2014). Zbliżone wnioski odnośnie instytucji certyfikujących można odnaleźć także w opracowaniu (Potrykus 2015). Ponadto w ostatnio cytowanej pracy stwierdzono również, że przeciętna różnica w wycenie diamentów o jednostopniowej różnicy w barwie - dla diamentów białych - wynosi ponad 11\%. Z kolei dla czystości jest to ponad $8 \%$, a dla jakości szlifu niespełna 5\%; jako najdroższą formę szlifu wskazano kształt kulisty. Do tej pory zostały także porównane stopy zwrotu $\mathrm{z}$ inwestycji w diamenty białe i w kolorach fantazyjnych. Wykazano, że diamenty białe odznaczały się średnią roczną nominalną, geometryczną stopą zwrotu na poziomie 8,1\%, zaś kamienie w kolorach fantazyjnych cechowały się stopą zwrotu na poziomie $7,4 \%$. Niższe stopy zwrotu notowano w przypadku pozostałych kamieni szlachetnych, takich jak rubiny, szafiry i szmaragdy. Dla nich stopa zwrotu kształtowała się na poziomie 4,5\% (Renneboog 2015). Przeprowadzona analiza dotyczyła okresu 1999-2012.

7 Firma EGL USA - działa na rynku blisko 30 lat, zaś GIA ponad 80 lat.

8 Szerzej w tym temacie: http://www.idexonline.com/FullArticle?id=25000 (dostęp: 21.12.2015). 
Fakt, że diamenty w kolorach fantazyjnych odznaczają się niższą stopą zwrotu niż diamenty bezbarwne, przedstawiono także w opracowaniu (Renneboog, Spaenjers 2012). Stopy zwrotu tam zaprezentowane wynoszą 10,0\%, 5,5\%, oraz 6,8\%, odpowiednio dla bezbarwnych kamieni, diamentów w kolorach fantazyjnych oraz pozostałych kamieni szlachetnych. Renneborg i Spaenjers wskazują jednocześnie, że kamienie bezbarwne osiągają wyższe stopy zwrotu niż te w kolorach fantazyjnych ze względu na fakt, że inwestorzy postrzegają te pierwsze jako bezpieczną przystań (ang. safe heaven) w czasach kryzysu. Co więcej na rynku diamentów występują punkty ogniskowe, co oznacza, że kamienie o wadze 1 karata są droższe (od 5\% do 10\%) niż te o wadze 0,99 karata. Podobne zależności występują także dla innych wag (Scott, Yelowitz 2010).

W przeprowadzonych do tej pory badaniach wskazano także na niewielką wartość współczynnika korelacji pomiędzy inwestycją w diamenty a rynkiem akcji oraz inwestycją w złoto (Small, Smith, Small 2013). Dla okresu badawczego przyjętego w cytowanym opracowaniu wartość współczynnika korelacji pomiędzy inwestycją w diamenty a indeksem S\&P 500 kształtowała się w przedziale ${ }^{9}$ od $-0,09$ do 0,18 . W przypadku złota i diamentów wartości otrzymywanych współczynników korelacji w okresie badawczym były zawsze mniejsze od zera, a najniższa z zaobserwowanych wartości wyniosła blisko -0,12. Dodatkowo autorzy Small, Smith i Small w swoim opracowaniu przedstawiają wartości współczynników korelacji w trzech podokresach. Są to odpowiednio: faza rozkwitu (lata 2002-2006), faza kryzysu (okres 2007-2009) oraz faza ożywienia (lata 2010-2011). W podanych podokresach również nie zanotowano wysokich wartości dla obliczonych współczynników korelacji. Najwyższa z zaobserwowanych wartości nie przekroczyła 0,35 przy zaznaczeniu, że dotyczyło to fazy ożywienia. Na podstawie tych badań autorzy stwierdzają, że inwestycja w diamenty jest wartościowym źródłem dywersyfikacji portfela inwestycyjnego. Podobne stwierdzenia na temat dywersyfikacji portfela, w skład którego wchodzą diamenty, pojawiają się także w artykule (Auer, Schuhmacher 2013). Zaś w pracy Borowskiego (Borowski 2014) zawarto stanowisko, że „zastosowanie diamentów do budowy portfela inwestycyjnego przyczynia się do przesunięcia granicy portfeli efektywnych - w ten sposób przy takim samym ryzyku inwestycyjnym możliwe jest uzyskanie wyższej stopy zwrotu $\mathrm{z}$ inwestycji”. Zalety inwestycji w diamenty, ze szczególnym uwzględnieniem ich wysokiej stopy zwrotu w okresie od 1985 do 2010 roku, przedstawiono ponadto w opracowaniu Kowgiera (Kowgier 2012).

Przywołane publikacje i wnioski w nich zapisane dotyczą w głównej mierze rynku bezbarwnych diamentów. Nie ma bowiem wielu opracowań akademickich, które podejmowałyby tematykę inwestowania w kamienie o kolorach fantazyjnych. To opracowanie powinno wypełnić tę lukę badawczą.

9 Osobno wyznaczono współczynniki korelacji liniowej Pearsona dla diamentów o wadze 1 karata w zależności od stopnia czystości oraz koloru, a także dla indeksu odzwierciedlającego stopy zwrotu dla rynku diamentów jako całości. Łącznie w pracy przeanalizowano 6 różnych szeregów czasowych dla inwestycji w diamenty. 
W poniższym opracowaniu do budowy modeli ekonometrycznych wykorzystano dane na temat 3031 diamentów w kolorach fantazyjnych. Dane pobrano z oferty dwóch sklepów handlujących kamieniami szlachetnymi: Blue Nile ${ }^{10}$ (2665 obserwacji) oraz Israel-Diamonds ${ }^{11}$ (366 obserwacji). Wszystkie ceny, które analizowano w tym opracowaniu, były wyrażone w dolarach amerykańskich. Dane zostały pobrane dwukrotnie, pierwszy raz 15.01.2015 roku (1370 obserwacji) oraz 15.12.2015 roku (1661 obserwacji). W opracowaniu analizie poddano diamenty w pięciu barwach. Te barwy to: niebieska, brązowa, zielona, różowa oraz żółta. Liczbę diamentów o określonych barwach wykorzystaną w analizie przedstawiono na rysunku 3.

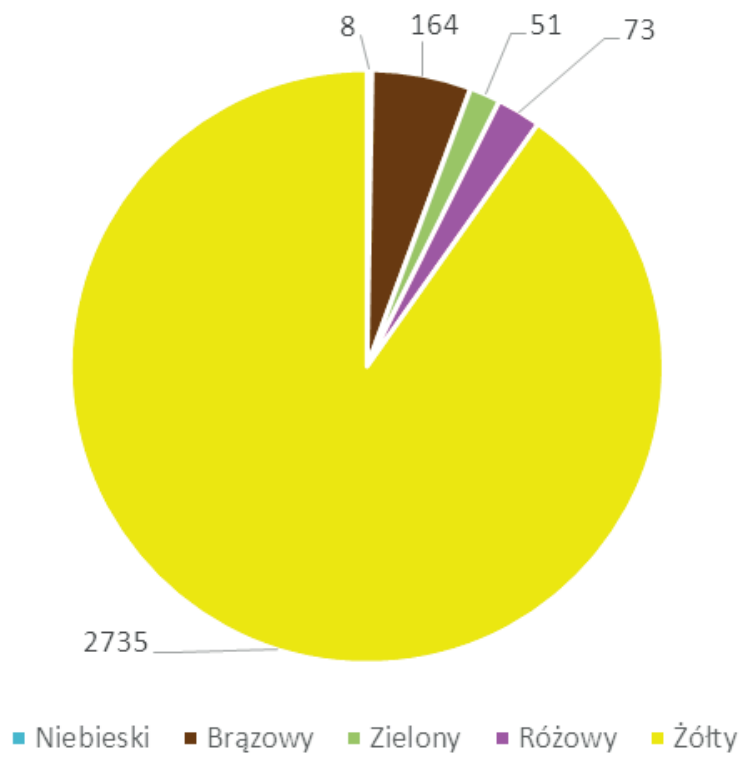

Rysunek 3. Liczba analizowanych kamieni w podziale na barwy

Źródło: opracowanie własne.

Najwięcej, bo blisko 90\%, spośród wszystkich kamieni poddanych analizie odznaczało się barwą żółtą. Druga najbardziej liczna grupa to kamienie brązowe. Zbliżoną liczbą obserwacji cechowały się diamenty o barwie różowej (73 kamienie) oraz zielonej (51 kamieni). Najmniej, bo jedynie 8 kamieni, było niebieskich. Przy określaniu barwy kamieni posłużono się zasadą uwzględniającą jedynie barwę dominującą. W takim przypadku, jeżeli diament był scharakteryzowany jako niebieskawo-zielony lub niebiesko-zielony, przyjmowano, że odznaczał się on barwą zieloną. Ponadto, jeżeli barwa diamentu była oznaczona jako szampańska (ang. champagne) lub koniak (ang. cognac), zgodnie z opracowaniem (Fink 2014), przyjmowano, że są to kamienie brązowe.

10 http://www.bluenile.com/

11 http://www.israel-diamonds.com/AboutUs.aspx 
W przypadku nazw określających ton i nasycenie, analizie poddano $6 \mathrm{z} 9$ wcześniej omówionych wariantów ${ }^{12}$ przedstawionych na rysunku 2 . Warianty poddane analizie ujęto w tabeli 1.

Tabela 1. Liczba kamieni wykorzystanych do budowy modeli ze względu na ton i nasycenie

\begin{tabular}{|c|l|l|c|}
\hline Lp. & Określenie tonu i nasycenia & Angielski odpowiednik nazwy & Liczba kamieni \\
\hline 1 & Ciemno-fantazyjny & Fancy Dark & 38 \\
\hline 2 & Głęboko-fantazyjny & Fancy Deep & 40 \\
\hline 3 & Fantazyjny & Fancy & 1500 \\
\hline 4 & Intensywnie-fantazyjny & Fancy Intense & 646 \\
\hline 5 & Jasno-fantazyjny & Fancy Light & 626 \\
\hline 6 & Żywo- lub ostro-fantazyjny & Fancy Vivid & 181 \\
\hline
\end{tabular}

Źródło: opracowanie własne.

Im wyższe nasycenie barwy, tym mniej dostępnych kamieni na rynku. W przypadku diamentów scharakteryzowanych jako ciemno-fantazyjne oraz głęboko-fantazyjne, ich liczba uwzględniona w badaniu wynosi, odpowiednio, 38 oraz 40. Dla kamieni, których ton i nasycenie określa się mianem fantazyjnych, odnotowano największą liczbę obserwacji, bo aż 1500. Można to łączyć z faktem, że na rysunku 2 dla tego pojęcia jest zarezerwowana największa powierzchnia. Porównywalna jest także liczba diamentów, których ton i nasycenie opisano jako intensywnie-fantazyjne oraz jasno-fantazyjne. W obu przypadkach liczba kamieni, których ceny poddano analizie, wynosi blisko 635 sztuk.

\section{Regresja hedoniczna jako metoda badawcza}

Dla określenia, jak barwa, ton oraz nasycenie wpływają na wycenę diamentów w kolorach fantazyjnych, zbudowano model regresji hedonicznej. Podstawą wyznaczania takiego modelu jest stwierdzenie, że dobra heterogeniczne mogą być opisane za pomocą poszczególnych charakterystyk lub ich atrybutów (de Haan, Diewert 2013). Stąd za pomocą modeli regresji hedonicznej można ocenić, jak barwa czy nasycenie wpływają na cenę diamentów ${ }^{13}$. Oznacza to, że końcowa wartość kamienia zależy od kombinacji poszczególnych charakterystyk, którymi dla diamentów są właśnie barwa, ton i nasycenie. Wyznaczony w pracy model przedstawia się następująco:

12 Pominięte trzy warianty dla tonu i nasycenia nie znalazły się w ofercie analizowanych sklepów w dniach pobierania danych.

13 Szerzej o metodzie regresji hedonicznej i budowie hedonicznych indeksów cenowych między innymi w pracach: (Taylor, Coleman 2011; Triplett 2004; Widłak 2010; Witkowska 2014). 


$$
\ln Y=\beta_{0}+\beta_{1} M A S A+\sum_{i=2}^{6} D_{i} \operatorname{TiN}_{i}+\sum_{i=7}^{10} D_{i} \text { Barwa }_{i}+\xi
$$

gdzie:

$Y$ - cena diamentu,

MASA - wyrażona w karatach masa kamienia,

$\operatorname{TiN}_{i}$ - zmienna zero-jedynkowa dla tonu i nasycenia kamienia,

Barwa $_{i}$ - zmienna zero-jedynkowa dla barwy kamienia,

$\xi$ - składnik losowy,

$\beta_{0}, \beta_{1}, D_{i}-$ parametry modelu.

Wartości oszacowanych parametrów przedstawionego wyżej modelu zapisano w tabeli 2. Dokonano oszacowania dla wszystkich 3031 obserwacji, a ponadto osobno dla diamentów z oferty sklepu Blue Nile oraz Isreal-Diamonds.

Tabela 2. Wyniki regresji hedonicznej dla diamentów w kolorach fantazyjnych

\begin{tabular}{|c|c|c|c|c|}
\hline \multirow[b]{2}{*}{ Zmienna } & \multirow[b]{2}{*}{$\begin{array}{c}\text { Oznaczenie } \\
\text { parametru } \\
\text { w modelu }\end{array}$} & \multicolumn{3}{|c|}{$\begin{array}{c}\text { Wartość oszacowanego parametru } \\
\text { po „odlogarytmowaniu” }\end{array}$} \\
\hline & & $\begin{array}{c}\text { Wszystkie } \\
\text { obserwacje } \\
(n=3031)\end{array}$ & $\begin{array}{c}\text { Tylko obserwacje } \\
\text { z Blue Nile } \\
(n=2665)\end{array}$ & $\begin{array}{c}\text { Tylko obserwacje } \\
\text { z Israel-Diamonds } \\
(n=366)\end{array}$ \\
\hline Wyraz wolny & $B_{0}$ & 22164,67 & 89285,00 & 2784,30 \\
\hline Masa & $B_{1}$ & 0,98 & 0,92 & 1,76 \\
\hline $\operatorname{TiN}_{2}$ (ciemno-fantazyjny) & $D_{2}$ & $-0,57$ & $-0,75$ & 0,04 (ns) \\
\hline $\begin{array}{l}\mathrm{TiN}_{3} \text { (głęboko- } \\
\text { fantazyjny) }\end{array}$ & $D_{3}$ & $-0,68$ & $-0,59$ & $-0,16(n s)$ \\
\hline $\operatorname{TiN}_{4}$ (fantazyjny) & $D_{4}$ & $-0,72$ & $-0,75$ & $-0,46$ \\
\hline $\begin{array}{l}\mathrm{TiN}_{5} \text { (intensywnie- } \\
\text { fantazyjny) }\end{array}$ & $D_{5}$ & $-0,59$ & $-0,62$ & $-0,32^{\star}$ \\
\hline $\operatorname{TiN}_{6}$ (jasno-fantazyjny) & $D_{6}$ & $-0,78$ & $-0,81$ & $-0,57$ \\
\hline $\begin{array}{l}\text { TiN (żywo- lub ostro- } \\
\text { fantazyjny) }\end{array}$ & & \multicolumn{3}{|c|}{$\begin{array}{l}\text { Zmienna usunięta z modelu dla uniknięcia } \\
\text { współliniowości }\end{array}$} \\
\hline Barwa $_{7}$ (niebieska) & $D_{7}$ & 5,77 & 2,56 & 3,00 \\
\hline Barwa $_{8}$ (brązowa) & $D_{8}$ & $-0,89$ & $-0,94$ & $-0,76$ \\
\hline Barwa $_{9}$ (zielona) & $D_{9}$ & $-0,62$ & $-0,88$ & $-0,12(n s)$ \\
\hline Barwa $_{10}$ (żółta) & $D_{10}$ & $-0,69$ & $-0,91$ & $-0,42$ \\
\hline Barwa (różowa) & & \multicolumn{3}{|c|}{$\begin{array}{l}\text { Zmienna usunięta z modelu dla uniknięcia } \\
\text { współliniowości }\end{array}$} \\
\hline Współczynnik determina & $\mathrm{cji} R^{2}$ & 0,700 & 0,732 & 0,737 \\
\hline
\end{tabular}

(ns) - parametr statystycznie nieistotny

* - parametr statystycznie istotny na poziomie $p=0,05$

Źródto: opracowanie własne. 
Dla uniknięcia współliniowości w wyznaczonych modelach z równania wyrugowano dwie zmienne: ton i nasycenie określone jako żywo- lub ostro-fantazyjne oraz różową barwę. Oznacza to, że pozostałe wartości oszacowanych parametrów w przypadku barwy odnoszą się do barwy różowej, a bazą porównawczą dla tonu i nasycenia jest żywo- lub ostro-fantazyjna. Na podstawie wartości oszacowanych parametrów po „odlogarytmowaniu” dla wszystkich danych można stwierdzić, że:

- Wzrost masy diamentu o jeden karat w kolorze fantazyjnym powoduje przeciętny wzrost ceny o 98\%, przy stałości pozostałych czynników.

- Diamenty o tonie i nasyceniu ciemno-fantazyjnym są przeciętnie o $57 \%$ tańsze niż te w tonie i nasyceniu określonym jako żywo- lub ostro-fantazyjny, przy stałości pozostałych czynników.

- Diamenty o tonie i nasyceniu głęboko-fantazyjnym są przeciętnie o $68 \%$ tańsze niż te w tonie i nasyceniu określonym jako żywo- lub ostro-fantazyjny, przy stałości pozostałych czynników.

- Diamenty o tonie i nasyceniu fantazyjnym są przeciętnie o $72 \%$ tańsze niż te w tonie i nasyceniu określonym jako żywo- lub ostro-fantazyjny, przy stałości pozostałych czynników.

- Diamenty o tonie i nasyceniu intensywnie-fantazyjnym są przeciętnie o 59\% tańsze niż te w tonie i nasyceniu określonym jako żywo- lub ostro-fantazyjny, przy stałości pozostałych czynników.

- Diamenty o tonie i nasyceniu jasno-fantazyjnym są przeciętnie o $78 \%$ tańsze niż te w tonie i nasyceniu określonym jako żywo- lub ostro-fantazyjny, przy stałości pozostałych czynników.

- Diamenty o dominującej barwie niebieskiej są przeciętnie droższe o 57\% niż te o dominującej barwie różowej, przy stałości pozostałych czynników.

- Diamenty o dominującej barwie brązowej są przeciętnie tańsze o 89\% niż te o dominującej barwie różowej, przy stałości pozostałych czynników.

- Diamenty o dominującej barwie zielonej są przeciętnie tańsze o $62 \%$ niż te o dominującej barwie różowej, przy stałości pozostałych czynników.

- Diamenty o dominującej barwie żółtej są przeciętnie tańsze o $69 \%$ niż te o dominującej barwie różowej, przy stałości pozostałych czynników.

Wartości wszystkich parametrów modelu, oszacowanego na podstawie obserwacji, znacznieróżnią się od zera na poziomie istotności $p=0,001$. Wartość współczynnika determinacji $R^{2}=0,700$, co oznacza, że 70\% zmienności zmiennej zależnej (ceny diamentu w kolorze fantazyjnym) zostało wyjaśnionych przez oszacowany model.

Dla wszystkich trzech modeli nie zaobserwowano różnic w kolejności wyceny ze względu na barwę kamienia. Oznacza to, że jako najdroższe zawsze były wskazywane kamienie o dominującej barwie niebieskiej. Następnie diamenty o dominującej barwie różowej, zielonej i żółtej. Jako najtańsze z kolei wskazano diamenty o dominującej barwie brązowej. W przypadku tonu i nasycenia nie ma już tak jednoznacznych wyników jak w przypadku barwy. Odnotowano jedynie, że bez względu na próbę badawczą najtańsze kamienie są określane jako jasno-fantazyjne. 
Nie występują co prawda znaczne różnice pomiędzy kolejnością wyceny tonu i nasycenia dla modelu uwzględniającego wszystkie dane a modelu uwzględniającego tylko dane ze sklepu Blue Nile. Jednak dołączenie do analizy otrzymanych wyników dla sklepu Israel-Diamonds wprowadza niewielkie różnice $\mathrm{w}$ otrzymanych wnioskach $^{14}$. Wydaje się, że powodem tego są dwie przyczyny. Po pierwsze niewielka próba badawcza dla sklepu Israel-Diamonds, a po drugie fakt, że oceny kamieni dokonywały różne instytucje certyfikujące, między innymi GIA, HRD czy IGI, które nie stosują całkowicie zbieżnych kryteriów przy ocenie tonu i nasycenia.

W następnym kroku do oszacowanego modelu dodano zmienną zero-jedynkową czasu. Postać funkcyjna modelu po tej zmianie przedstawia się następująco:

$$
\ln Y=\beta_{0}+\beta_{1} M A S A+\sum_{i=2}^{6} D_{i} \operatorname{TiN}_{i}+\sum_{i=7}^{10} D_{i} \text { Barwa }_{i}+D_{11} C_{z a s_{15.12 .2015}}+\xi
$$

gdzie:

Czas $_{15.12 .2015}$ - zmienna zero-jedynkowa dla czasu,

$D_{11}$ - parametr modelu.

Pozostałe oznaczenia - jak wyżej.

Zmienna Czas $_{15.12 .2015}$ przyjmowała wartość 1, jeżeli kamień znajdował się w ofercie w dniu 15.12.2015 roku, w przeciwnym wypadku wartość tej zmiennej wynosiła zero. Podobnie jak wcześniej dla zmiennej barwa oraz ton i nasycenie, aby uniknąć w modelu występowania współliniowości, z równania wyrugowano

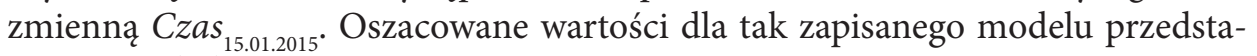
wiono w tabeli 3 .

Na podstawie oszacowanej wartości parametru $D_{11}$ można stwierdzić, że wartość diamentów w kolorach fantazyjnych od 15.01.2015 do 15.12.2015 roku zmniejszyła się przeciętnie o 21,6\%. Podobne zależności w 2015 roku, jednak w mniejszym stopniu, potwierdzono dla diamentów bezbarwnych. Odnotowano bowiem spadek o blisko $12 \%{ }^{15}$. Załamanie cen na rynku diamentów jest spowodowane wydarzeniami z połowy 2015 roku, kiedy znacząco obniżył się popyt na kamienie szlachetne ze strony chińskich inwestorów, co było konsekwencją spowolnienia drugiej największej gospodarki świata (Barnato 2015). W skutek tego w sierpniu 2015 roku najmniejsze diamenty bezbarwne notowały roczną stopę zwrotu na poziomie -30\%. Do tak znacznych spadków cen diamentów przyczyniło się także działanie firmy De Beers (jednego z największych dystrybutorów diamentów na świecie), która znacząco, bo blisko o 10\%, obniżyła ceny tych kamieni szlachetnych, aby zwiększyć drastycznie malejący popyt (Biesheuvel 2015). Te wydarzenia

$14 \mathrm{~Np}$. ton i nasycenie ciemno-fantazyjne jest drożej wyceniane w sklepie Israel-Diamonds niż ton i nasycenie żywo- lub ostro-fantazyjne, co nie ma miejsca w sklepie Blue Nile.

15 Taki spadek potwierdzają źródła: http://www.paulzimnisky.com/roughdiamondindex; https://www.polishedprices.com/ 
nie pozostały także bez wyraźnego wpływu na ceny diamentów w kolorach fantazyjnych, czego wyrazem jest oszacowany spadek sięgający średnio blisko $22 \%$. Obliczona stopa zwrotu wpisuje się ponadto w ujemne stopy zwrotu na innych rynkach. Przykładem są tutaj rynki surowcowe, na których odnotowano spadki cen dla ropy naftowej o blisko $22 \%$, złota o blisko $15 \%$, platyny o ponad $30 \%{ }^{16}$.

Tabela 3. Wyniki regresji hedonicznej dla diamentów w kolorach fantazyjnych z uwzględnieniem zmiennej czasu

\begin{tabular}{|c|c|c|c|}
\hline \multicolumn{4}{|c|}{ Model 2: Estymacja KMNK, wykorzystane obserwacje 1-3031 } \\
\hline \multicolumn{4}{|c|}{ Zmienna zależna (Y): I_Cena } \\
\hline Zmienna & $\begin{array}{l}\text { Oznaczenie } \\
\text { parametru } \\
\text { w modelu }\end{array}$ & $\begin{array}{c}\text { Wartość } \\
\text { oszacowanego parametru } \\
\text { po „odlogarytmowaniu” }\end{array}$ & wartość p \\
\hline Wyraz wolny & $B_{0}$ & 23478,90 & 0 \\
\hline Masa & $B_{1}$ & 0,963 & 0 \\
\hline TiN2 (ciemno-fantazyjny) & $D_{2}$ & $-0,549$ & $1,39 \mathrm{E}-08$ \\
\hline TiN3 (głęboko-fantazyjny) & $D_{3}$ & $-0,676$ & $1,7 \mathrm{E}-18$ \\
\hline TiN4 (fantazyjny) & $D_{4}$ & $-0,704$ & $3,14 \mathrm{E}-94$ \\
\hline TiN5 (intensywnie-fantazyjny) & $D_{5}$ & $-0,577$ & $1,18 \mathrm{E}-44$ \\
\hline TiN6 (jasno-fantazyjny) & $D_{6}$ & $-0,771$ & $5,33 \mathrm{E}-118$ \\
\hline Barwa7 (niebieska) & $D_{7}$ & 5,231 & $9,08 \mathrm{E}-12$ \\
\hline Barwa8 (brązowa) & $D_{8}$ & $-0,886$ & $2,1 \mathrm{E}-89$ \\
\hline Barwa9 (zielona) & $D_{9}$ & $-0,571$ & $1,98 \mathrm{E}-10$ \\
\hline Barwa10 (żółta) & $D_{10}$ & $-0,674$ & $4,35 \mathrm{E}-38$ \\
\hline Czas $_{15.01 .2015}$ & $D_{11}$ & $-0,216$ & $1,78 \mathrm{E}-19$ \\
\hline Średn. aryt. zm. zależnej & 8,633 & Odch. stand. zm. zależnej & 1,324 \\
\hline Suma kwadratów reszt & 1547,708 & Błąd standardowy reszt & 0,716 \\
\hline Wsp. determ. $R$-kwadrat & 0,709 & Skorygowany $R$-kwadrat & 0,708 \\
\hline$F(11,3019)$ & 667,782 & Wartość $p$ dla testu $\mathrm{F}$ & 0,000 \\
\hline Logarytm wiarygodności & $-3282,209$ & Kryt. inform. Akaike'a & 6588,417 \\
\hline Kryt. bayes. Schwarza & 6660,617 & Kryt. Hannana-Quinna & 6614,374 \\
\hline
\end{tabular}

Źródto: opracowanie własne.

16 Wyliczeń dokonano na podstawie danych Banku Światowego. 


\section{Podsumowanie}

Na podstawie przeprowadzonych badań literaturowych wykazano, że kluczowe czynniki przy wycenie diamentów w kolorach fantazyjnych to oprócz wagi kamienia także barwa, ton oraz nasycenie. Ponadto wykazano, że istotny wkład w rozwój standaryzacji oceny kamieni w kolorach fantazyjnych wniosła instytucja Gemological Institute of America. Na podstawie przeprowadzonych analiz stwierdzono również, że najwyższe ceny osiągają kamienie o dominującej barwie niebieskiej, następnie różowej i kolejno zielonej, żółtej i brązowej. W stosunku do barwy różowej kamienie niebieskie są przeciętnie droższe o ponad 57. Zaś kamienie o dominującej barwie zielonej, żółtej lub brązowej są odpowiednio tańsze o 62\%, 69\% i $89 \%$ w porównaniu do diamentów różowych. W przypadku tonu i nasycenia, najwyższe ceny osiągają kamienie charakteryzowane jako żywo- lub ostro-fantazyjne, ciemno-fantazyjne lub intensywnie-fantazyjne. Przy czym diamenty o tonie i nasyceniu ciemno- lub intensywnie-fantazyjnym są o blisko $60 \%$ tańsze niż te, które określa się jako żywo- lub ostro-fantazyjne.

Za pomocą przeprowadzonej analizy stwierdzono również, że średnie ceny analizowanych kamieni obniżyły się na przestrzeni 2015 roku o blisko 22\%. Była to reakcja na zmniejszenie podaży ze strony chińskich inwestorów oraz obniżenie cen przez wiodącego światowego dystrybutora diamentów - firmę De Beers. Znacznej przecenie diamentów (nie tylko w kolorach fantazyjnych) w roku 2015 towarzyszyły także obniżone stopy zwrotu $\mathrm{z}$ inwestycji na rynku ropy naftowej czy metali szlachetnych.

\section{Bibliografia}

Auer B.R., Schuhmacher F. (2013), International Review of Financial Analysis Diamonds - A precious new asset?, International Review of Financial Analysis, 28, p. 182-189.

Barnato K. (2015), Diamond prices hit by stock market slump, China, http://www.cnbc.com/2015/09/10/ diamond-prices-hit-by-stock-market-slump-china.html (dostęp: 09.01.2016).

Betts J.H., Nikischer T. (2014), Collecting Diamonds and the Kimberley Process, Rocks \& Minerals, 89, p. 89-90.

Biesheuvel T. (2015), De Beers Said to Cut Diamond Prices as Much as 9\%, http://www.bloomberg. com/news/articles/2015-08-24/de-beers-said-to-cut-diamond-prices-as-much-as-9-on-weak-demand (dostęp: 09.01.2016).

Borowski K. (2014), Analiza uwarunkowań inwestycyjnych na rynku diamentów, Modern Management Review, XIX, s. 25-45.

Breeding C.M., Shigley J.E. (2009), The "Type" Classification System of Diamonds and its Importance in Gemology, Gems \& Gemology, 45(2), p. 96-111.

de Haan J., Diewert E. (2013), Handbook on Residential Property Price Indices, [in:] Handbook on Residential Property Price Indices, OECD, p. 49-64. 
Fink C. (2014), Rise from the rough: The growing demands on the brown diamond market, Journal of Brand Strategy, 3(4), p. 332-338.

Hofer S.C. (1998), Collecting and classifying coloured diamonds, Ashland Press, New York.

Jagielnicki A. (2011), Inwestycje alternatywne. Pierwsze kroki na rynku pozagiełdowym, Helion, Gliwice.

King J.M. (2006), GIA Colored diamonds color reference charts (1st ed.), The Gemological Institute of America, http://www.bluenile.com/education/diamonds/colored-diamonds

King J.M., Moses T.M., Shigley J.E., Liu Y. (1994), Color grading of colored diamonds in the GIA gem trade laboratory, Gems \& Gemology, 30(4), p. 220-242.

Kowgier H. (2012), Kilka uwag o diamentach, Zeszyty Naukowe ZPSB - Firma i Rynek, 2(43), s. 68-75.

Lee J.A., Caudill S.B., Mixon F.G. (2014), Shine bright like a diamond: a hedonic model of grading and pricing an experience good, Applied Economics, 46(16), p. 1829-1838.

Matlins A.L., Bonanno A.C. (1989), Jewelry@ Gems. The buying guide, Journal of Chemical Information and Modeling, II, Vol. 53, GemStone Press, Vermont.

Ostrowska E. (2011), Portfel inwestycyjny klasyczny i alternatywny, C.H. Beck, Warszawa.

Potrykus M. (2015), Diamenty jako przykład inwestycji alternatywnej, Nauki O Finansach = Financial Sciences, 2(23), s. 110-126.

Renneboog L. (2015), Investing in Diamonds, Business and Economic Research, 5, p. 166-195.

Renneboog L., Spaenjers C. (2012), Hard assets: The returns on rare diamonds and gems, Finance Research Letters, 9(4), p. 220-230.

Scott F., Yelowitz A. (2010), Pricing Anomalies in the Market for Diamonds: Evidence of Conformist Behavior, Economic Inquiry, 48(2), p. 353-368.

Shor R. (2013), Auction Houses: A Powerful market influence on major diamonds and colored gemstones, Gems \& Gemology, 49(1), p. 2-15.

Small K., Smith J., Small E. (2013), The return characteristics of diamonds, The Journal of Investing, 22, p. 132-143.

Taylor D., Coleman L. (2011), Price determinants of Aboriginal art, and its role as an alternative asset class, Journal of Banking \& Finance, 35(6), p. 1519-1529.

Triplett J. (2004), Handbook on Hedonic Indexes and Quality Adjustments in Price Indexes: Special Application To Information Technology Products, Technology and Industry Working Papers, Paris.

Widłak M. (2010), Dostosowanie indeksów cenowych do zmian jakości. Metoda wyznaczania hedonicznych indeksów cen i możliwości ich zastosowania dla rynku mieszkaniowego, Materiały i Studia, (247), s. 1-29.

Witkowska D. (2014), An Application of Hedonic Regression to Evaluate Prices of Polish Paintings, International Advances in Economic Research, 20, 281-293.

http://4csblog.gia.edu/2014/celebrate-20-years-colored-diamond-grading-system (dostęp: 17.12.2015). http://www.bluenile.com (dostęp: 17.12.2015).

http://www.gia.edu/fancy-color-diamond (dostęp: 17.12.2015).

http://www.idexonline.com/FullArticle?id=25000 (dostęp: 21.12.2015).

http://www.israel-diamonds.com/AboutUs.aspx (dostęp: 17.12.2015). 


\section{DIAMENTY W KOLORACH FANTAZYJNYCH - CHARAKTERYSTYKA WALORÓW INWESTYCYJNYCH}

\section{Streszczenie}

$\mathrm{W}$ artykule scharakteryzowano czynniki determinujące stopę zwrotu $\mathrm{z}$ inwestycji $\mathrm{w}$ diamenty w kolorach fantazyjnych. Cel opracowania to wskazanie kryteriów, które decydują o przypisaniu do konkretnego diamentu określonej barwy. Ponadto w pracy zbadano, jak barwa, ton oraz nasycenie wpływają na wycenę diamentów w kolorach fantazyjnych. Co więcej, za pomocą regresji hedonicznej zbadano, jak zmieniła się wartość analizowanych kamieni w 2015 roku. Na podstawie przeprowadzonych analiz stwierdzono, że najwyższe ceny osiągają kamienie o dominującej barwie niebieskiej, następnie różowej i kolejno zielonej, żółtej i brązowej. W stosunku do barwy różowej kamienie niebieskie są przeciętnie droższe o ponad 57. Zaś kamienie o dominującej barwie zielonej, żółtej lub brązowej są odpowiednio tańsze o 62\%, 69\% i 89\% w porównaniu do diamentów różowych. W przypadku tonu i nasycenia najwyższe ceny osiągają kamienie charakteryzowane jako żywo- lub ostro-fantazyjne, ciemno-fantazyjne lub intensywnie-fantazyjne. Przy czym diamenty o tonie i nasyceniu ciemno- lub intensywnie-fantazyjnym są o blisko $60 \%$ tańsze niż te, które określa się jako żywo- lub ostro-fantazyjne. Za pomocą przeprowadzonej analizy stwierdzono również, że średnie ceny analizowanych kamieni obniżyły się na przestrzeni 2015 roku o blisko $22 \%$.

Słowa kluczowe: diamenty w kolorach fantazyjnych, inwestowanie, regresja hedoniczna

\section{FANCY COLORED DIAMONDS - CHARACTERISTICS OF INVESTING PROPERTIES}

\section{Summary}

The article describes the factors determining the rate of return on investment in fancy colored diamonds. Purpose of this paper is an indication which criteria are major factor to assign a specific colour to particular diamond. In addition, the study investigated as colour, tone and saturation affect the valuation of diamonds in a fancy colours. Moreover, using hedonic regression author examined the changes in value of the studied stones in 2015. It was found that the highest prices reach gems of the dominant colour blue or pink and then green, yellow and brown. In relation to the pink colour, blue stones are on average more expensive by over $57 \%$, and stones with a dominant colour green, yellow or brown are cheaper respectively by $62 \%, 69 \%$ and $89 \%$ compared to pink diamonds. In the case of tone and saturation, the highest prices are reached by fancy vivid or fancy dark stones. When the diamonds tone and saturation are described as fancy dark or fancy intense then this stones are nearly $60 \%$ cheaper than those which are referred as a fancy vivid. Author also found that the average prices of the examined stones fell over 2015 nearly by $22 \%$.

Keywords: fancy colored diamonds, investing, hedonic regression 